Original Research

\title{
Effectiveness of an Intervention based on Peplau's Model on Health Literacy among Nurses Who Smoke: A Quasi-Experimental Study
}

\section{Achmad Djojo ${ }^{1}$, Suhariyanto Suhariyanto' ${ }^{1}$, Lily Yuniar ${ }^{1}$, Arsad Suni' ${ }^{2}$ Efi Riani ${ }^{1}$, Yogi Ervandi $^{1}$, Sepni Walvri ${ }^{1}$, Angie Aprizal ${ }^{1}$, Rr Tutik Sri Hariyati ${ }^{3}$ and Hanny Handiyani ${ }^{3}$}

${ }^{1}$ Jurusan Keperawatan Singkawang, Poltekkes Kemenkes Pontianak, Pontianak, Indonesia

2 Poltekkes Kemenkes Ternate, Indonesia

${ }^{3}$ Faculty of Nursing Science, Universitas Indonesia, Depok, Indonesia

\begin{abstract}
Introduction: : Lack of health literacy for smoking nurses has worsened image of nursing services. The role of leader can be a support in increasing behavior change of nurses who smoke. The aimed to find out health literacy of smokers in nursing staff through interpersonal role of the head of the room by intervention based on Peplau's model.
\end{abstract}

Methods: A quasi-experimental research with a pre-and post-control group design, using modification questionnaire of knowledge and behavior. The target population was nurses living in Singkawang who smoke in a hospital. Sample was 35 respondents for each group (controlling group and intervention group) using purposive sampling. Dependent variable is health literacy among nurses who smoke and independent variable is intervention based on Peplau's model. Intervention is in the form of a guide module consisting of strengthening health literacy (health awareness, self-reflection, cognitive competence and behavioral interpersonal relationships in the head of the room) and will be implemented to nurses who smoke. Analysis data for bivariate used paired $\mathrm{t}$ - test and for multivariate used the McNemar test.

Results: The research showed that the difference before and after intervention was $2.23(\mathrm{p}=0.001$ ) and control group was 8.00 with a default value of 0.870 deviation. The results showed a significant increase in health literacy in nurse smokers through the role of interpersonal head nurse $(\mathrm{p}=0.001)$.

Conclusion: Role of head of room in interpersonal relationship with Peplau's model affects the health literacy of nursing staff who smoke.

\section{ARTICLE HISTORY}

Received: August 17, 2020

Accepted: October 20, 2020

\section{KEYWORDS}

head of nurse; peplau's model; health literacy; smoking; guide module

\section{CONTACT}

Suhariyanto Suhariyanto $\triangle$

suhariyantoputra1986@gm ail.com

$\supseteqq$ Poltekkes Kemenkes Pontianak, Pontianak, Indonesia

Cite this as: $\quad$ Djojo, A., Suhariyanto, S., Yuniar, L., Suni, A., Riani, E., Ervandi, Y., et al. (2020). The Relationship between Family Harmony with Stress, Anxiety, and Depression in Adolescents. Jurnal Ners, 15(2). 194-198. doi:http://dx.doi.org/10.20473/jn.v15i2.21444

\section{INTRODUCTION}

Nurses are role model who provide education for patients or community to change for better behavior (Morsiani, Bagnasco and Sasso, 2017). Nurses who don't have good health awareness are given interventions to change these behaviors (Morsiani, Bagnasco and Sasso, 2017; Kirkman et al., 2018). Nurses' health literacy can be formed through interpersonal relationships that can change the way they think about health behavior. The findings indicate that healthcare professionals need support from leaders and coworkers, who play an important role in promoting behavior change (Blackstone and Pressman, 2016; Morsiani, Bagnasco and Sasso, 2017). Other studies suggest that positive support, training, motivating, and disciplined healthcare personnel promote increased adherence that changes behavior (Renner et al., 2012). The ability to understand individual behavior requires a nursing theory approach, which is a theory developed by Peplau regarding interpersonal relationships that help carry out their duties through cooperative relationships (Canadian Interprofessional Health 
Collaborative, 2010). The interpersonal relationships that are built can influence changes in affective, cognitive, and multidimensional behavior by using several positive social and interpersonal interventions (Choi et al., 2016). The approach through health professionals, especially nurses, has a role in maintaining patient safety by providing patient and family education (Scully, 2015). In addition, one of the competencies of nurses is being able to apply interpersonal relationships to provide education and examples for patients in changing behavior.

Health literacy rate of nurses in implementing health has not yet reached the standard level, more than $50 \%$ of nurses in developing countries still need higher education and support (Niederdeppe et al., 2008; Seymour, 2018). The results of a preliminary study and encroachment carried out in five hospitals in Kalimantan in May 2019 showed that the level of knowledge and health literacy was still low (45\%) and moderate $(55 \%)$. The results of interviews with the head of nursing and medical services for health workers stated that most male nurses had smoking behavior, even though information on smoking bans in the hospital already existed. The results of observations also show that health workers still smoke around the hospital, both in the surrounding area and in the canteen. Bad health literacy carried out by nurses can make patients and their families to not believe in the education provided by nurses, because of the behavior they see (Choi et al., 2016). The phenomenon of nurse behavior not having high health literacy needs to be changed, so that the quality of nursing and hospital services improves. In addition, patient and family satisfaction is important for maintaining the existence of the hospital and accreditation. Good services can improve the health status of patients, thereby supporting the SDGs 2030 program of healthy living and promoting welfare for all communities. This study aim was to find out health awareness of smokers in nursing staff through the interpersonal role of the head of the room by intervention based on Peplau's model.

\section{MATERIALS AND METHODS}

This research is a quasi-experimental study with pre and post-control group design, which was held for six months at hospital in Kalimantan with criteria of hospitals that have a large number of smoking nurses. The target population was nurses who smoke in a hospital and lives in Singkawang. Researchers selected research respondents using purposive sampling technique with the inclusion criteria being male nurses, productive age and active smokers, while the exclusion criteria were nurses who had quit smoking and were unwilling to be observed. There are 70 respondents that contain 35 respondents for control group and 35 respondents for intervention group. Dependent variable is health literacy among nurses who smoke and independent variable is intervention based on Peplau's model. Intervention is in the form of a guide module consisting of strengthening health literacy and implemented to nurses who smoke. Instruments of this study consist of guide module (strengthening health awareness, self-reflection, cognitive competence and behavioral interpersonal relationships in the head of the room) and health awareness questionnaire with 49 items using Likert scale. After dividing into two groups, we did pretest then gave intervention with guide module (strengthening health awareness, selfreflection, cognitive competence and behavioral interpersonal relationships in the head of the room). Analysis data for bivariate used paired $t$ - test and for multivariate used McNemar test. This study was accepted for ethical clearance from Poltekkes Kemenkes Pontianak No. 191/KEPK-PK.PKP/V/ 2019.

\section{RESULTS}

The research conducted in 35 respondents in each group showed that all respondents were male. The highest educational background of the nurses was diploma (intervention vs. control; $88.6 \%$ vs. $85.7 \%$ ) and the average of age of each group was $26-30$ years. The majority respondents were permanent employee with working period average 3-4 years (Table 1).

There are differences between intervention group before and after giving intervention; before intervention the intervention group mean was 7.76 and increased after intervention to 10.00 with p value 0.001, while in the control group with 35 respondents the average health literacy obtained a value of 8.00 with a default value of 0.870 deviation (Table 2). Based on the results of the calculation of the statistical test, it was obtained $\mathrm{p}=0.001$. This means that the $\mathrm{p}$ value $<\alpha=0.05$ ), which states that the interpersonal role of the head of the room strengthens the interpersonal role with the Peplau's model affecting the health literacy of nursing staff. For head of the room, there are guide modules that can increase the knowledge about interpersonal role with Peplau's model and which consist of role of teaching and resource persons, leadership role, role of guardian, advisory role and role of the stranger. It will be implemented to nursing staff who smoke using Peplau's model, so health literacy among nurses who smoke will increase.

\section{DISCUSSION}

Health literacy is defined as a person's ability to obtain, process, and understand health information and healthcare that is necessary so as to make appropriate decisions for individual health conditions. The health literacy of respondents who are smoking nurses is to be aware of the knowledge and motivation to change (DeWalt et al., 2011; Sheridan et al., 2011). In this study, before the respondents were given intervention, the head of the room was given a guide module containing interpersonal roles with Peplau's model. After that, 
Table 1. Distribution of Respondent Characteristics

\begin{tabular}{|c|c|c|c|c|c|c|}
\hline \multirow{2}{*}{ Parameter } & \multicolumn{2}{|c|}{ Intervention } & \multicolumn{2}{|c|}{ Control } & \multicolumn{2}{|c|}{ Total } \\
\hline & $\mathbf{n}$ & $\%$ & $\mathbf{n}$ & $\%$ & $\mathbf{n}$ & $\%$ \\
\hline \multicolumn{7}{|l|}{ Gender } \\
\hline Male & 35 & 100 & 35 & 100 & 70 & 100 \\
\hline \multicolumn{7}{|l|}{ Age } \\
\hline 20-25 year & 15 & 42.8 & 12 & 34.3 & 27 & 38.5 \\
\hline 26-30 year & 10 & 38.5 & 17 & 48.6 & 27 & 38.5 \\
\hline 31-35 year & 10 & 28.7 & 6 & 17.1 & 16 & 23 \\
\hline \multicolumn{7}{|l|}{ Education } \\
\hline Bachelor & 4 & 11.4 & 5 & 14.3 & 9 & 12.8 \\
\hline Diploma & 31 & 88.6 & 30 & 85.7 & 61 & 87.2 \\
\hline \multicolumn{7}{|l|}{ Employment Status } \\
\hline Permanent employee & 21 & 60.0 & 19 & 54.3 & 40 & 57 \\
\hline Contract employee & 14 & 40.0 & 16 & 45.7 & 30 & 43 \\
\hline \multicolumn{7}{|l|}{ Working duration } \\
\hline$<1$ year & 5 & 14.3 & 6 & 17.1 & 11 & 15.7 \\
\hline $1-5$ year & 17 & 48.6 & 13 & 37.1 & 30 & 42.8 \\
\hline$>5$ year & 13 & 37.1 & 16 & 45.8 & 29 & 41.5 \\
\hline
\end{tabular}

Table 2. The Difference of Health Literacy of the Respondents

\begin{tabular}{|c|c|c|c|c|c|c|c|}
\hline No & \multicolumn{2}{|c|}{ Health literacy } & $\mathbf{N}$ & Mean & Mean Differences & SD & $\mathbf{p}$ \\
\hline \multirow{2}{*}{1} & \multirow{2}{*}{ Intervention group } & Before & 35 & 7.76 & 2.23 & 1.550 & 0.001 \\
\hline & & After & 35 & 10.00 & & 0.870 & \\
\hline 2 & Control group & $\begin{array}{l}\text { Before } \\
\text { After }\end{array}$ & 35 & 8.00 & & 0.870 & 0.037 \\
\hline
\end{tabular}

the head of the room implemented it to nursing staff. The result of this study shows that afterwards the intervention group increased health literacy; before intervention the mean was 7.76 and after intervention it was 10.00 with $p$ value 0.001 , which means $p$ value $<\alpha=0.05$ ) indicating the interpersonal role of the head of the room strengthens the interpersonal role with the Peplau's model affecting the health literacy of nursing staff.

Sorensen stated that the causes of low health literacy include increasing age, latest education level, motivation, and individual behavior. It has been researched by Sorensen et al. (2012) that motivation also affects a person's ability to seek information about health and try to understand what is obtained from that information (Kim, 2009; Protheroe, Wolf and Lee, 2010; Berkman et al., 2011). The result of this research supports the theory found by other researchers. Persons with low health literacy have low knowledge of health, while a person with high health literacy has good knowledge of health (Lee, Lee and Moon, 2016). In this study, there was no difference in the control group results because it wasn't given treatment. In this case, it is necessary to have a continuous mentoring from the field of nursing to perform competence as head nurse in conducting interpersonal Peplau. It cannot be done only one or twice, but must be continuous (Mosley and Taylor, 2017). The motivation also affects a person's ability to seek information about health and seek to understand what the information provides. The motivation is gained from interpersonal head of room with Peplau's model. This is supported by the head of room providing support and commitment to the goal that raises productivity and can motivate the work behavior of nurses.
The competency of head nurses in implementing leadership functions is the most dominant factor affecting the health literacy in nurses (Laschinger et al., 2014; Marquis and Huston, 2017). Leadership roles and managerial head of room are important in applying interpersonal Peplau's model. This role can't be given only once, but needs to be continuous in the form of continuous supervision of the head of nurse to the staff who are smoking in order to create health literacy. A briefing function that is included in the interpersonal role of the head nurse is one of the forms of leadership management to increase effectiveness and efficiency in working further to create a healthy work environment because the head of room is capable to direct to nursing staff (Scully, 2015; Marquis and Huston, 2017). It is influenced by the ability and responsibility of the head of room and the cooperation of nurses in the room.

Interpersonal relationships are one of the measures to change viewpoints related to health behavior. Findings suggest that healthcare professionals need the support of leaders and peers, who play an important role in raising behavioral changes (Barrantes et al., 2017; Ogoncho, Sanga and Halake, 2017). The ability to understand behavior requires an approach to nursing theory. The Hildegard Peplau Theory (1952) focuses on individuals, nurses, and the interactive process; the results show the relationship between nurses and clients. Based on this theory, the client is an individual with a feeling of need, and nursing is an interpersonal and therapeutic process. The goal of nursing is to educate clients and families and to help clients achieve personality development maturity. Therefore, nurses seek to develop a relationship between nurses and clients, where nurses serve as 
speakers, counselors, and guardians. When the client seeks help, the nurse first discusses the problem and explains the type of service available. With the growing relationship between nurses and clients, nurses and clients together define problems and possibly resolve the problem. From this relationship, the client benefits by utilizing the available services to meet his needs and nurses assist the client in terms of lowering the anxiety associated with his health problems.

\section{CONCLUSION}

Based on this study regarding the health literacy of smokers in nursing staff through the interpersonal role of the head of the room with the strengthening of the Peplau's model, it can be concluded that there is an influence of the interpersonal role of the head of the room with Peplau's model on the health literacy of nursing staff. The role of head of room in interpersonal relationships using Peplau's model affects the health literacy of nursing staff who smoke. This role cannot be assigned once, but needs to be continuous in the form of continuous supervision from the head of the room to the smoking staff so as to create health literacy.

\section{REFERENCES}

Barrantes, R. J. et al. (2017) 'The role of minority stressors In lesbian relationship commitment and persistence over time', Psychology of Sexual Orientation and Gender Diversity. doi: 10.1037/sgd0000221.

Berkman, N. D. et al. (2011) 'Low health literacy and health outcomes: An updated systematic review', Annals of Internal Medicine. doi: 10.7326/00034819-155-2-201107190-00005.

Blackstone, S. W. and Pressman, H. (2016) 'Patient Communication in Health Care Settings: New Opportunities for Augmentative and Alternative Communication', AAC: Augmentative and Alternative Communication. doi: 10.3109/07434618.2015.1125947.

Canadian Interprofessional Health Collaborative (2010) A National Interprofessional Competency Framework, Health San Francisco.

Choi, S. L. et al. (2016) 'Transformational leadership, empowerment, and job satisfaction: The mediating role of employee empowerment', Human Resources for Health. doi: 10.1186/s12960-016-0171-2.

DeWalt, D. A. et al. (2011) 'Developing and testing the health literacy universal precautions toolkit', Nursing Outlook. doi: 10.1016/j.outlook.2010.12.002.

Kim, S. H. (2009) 'Health literacy and functional health status in Korean older adults', Journal of Clinical Nursing. doi: 10.1111/j.13652702.2008.02739.x.
Kirkman, T. et al. (2018) 'Strategies for implementing a multiple patient simulation scenario', Nurse Education Today.

10.1016/j.nedt.2018.01.032.

Laschinger, H. K. S. et al. (2014) 'Resonant leadership and workplace empowerment: the value of positive organizational cultures in reducing workplace incivility.', Nursing economic\$.

Lee, E. H., Lee, Y. W. and Moon, S. H. (2016) 'A Structural Equation Model Linking Health Literacy to Self-efficacy, Self-care Activities, and Healthrelated Quality of Life in Patients with Type 2 Diabetes', Asian Nursing Research. doi: 10.1016/j.anr.2016.01.005.

Marquis, B. L. and Huston, C. J. (2017) Leadership roles and management functions in nursing: Theory and application, Leadership Roles and Management Functions in Nursing: Theory and Application. doi: 10.1097/00006216-200407000-00013.

Morsiani, G., Bagnasco, A. and Sasso, L. (2017) 'How staff nurses perceive the impact of nurse managers' leadership style in terms of job satisfaction: a mixed method study', Journal of Nursing Management. doi: 10.1111/jonm.12448.

Mosley, C. M. and Taylor, B. J. (2017) 'Integration of Health Literacy Content Into Nursing Curriculum Utilizing the Health Literacy Expanded Model', Teaching and Learning in Nursing. doi: 10.1016/j.teln.2016.12.005.

Niederdeppe, J. et al. (2008) 'Message design strategies to raise public awareness of social determinants of health and population health disparities', Milbank Quarterly. doi: 10.1111/j.1468-0009.2008.00530.x.

Ogoncho, I. M., Sanga, P. and Halake, D. G. (2017) ‘Case Management of Substance Induced Psychosis Using Peplau ' $s$ Theory of Interpersonal Relations', Clinical Practice. doi: 10.5923/j.cp.20170602.03.

Protheroe, J., Wolf, M. S. and Lee, A. (2010) 'Health literacy and health outcomes', in Health Literacy in Context: International Perspectives.

Renner, B. et al. (2012) 'Dynamic psychological and behavioral changes in the adoption and maintenance of exercise', Health Psychology. doi: $10.1037 / \mathrm{a} 0025302$.

Scully, N. J. (2015) 'Leadership in nursing: The importance of recognising inherent values and attributes to secure a positive future for the profession', Collegian. doi: 10.1016/j.colegn.2014.09.004.

Seymour, J. (2018) 'The Impact of Public Health Awareness Campaigns on the Awareness and Quality of Palliative Care', Journal of Palliative Medicine. doi: 10.1089/jpm.2017.0391. 
A. DJOJO ET AL.

Sheridan, S. L. et al. (2011) 'Interventions for individuals with low health literacy: A systematic review', in Journal of Health Communication. doi: 10.1080/10810730.2011.604391. 